\title{
The Taxation of Multinationals: Firm Level Evidence for Belgium
}

\author{
Hylke Vandenbussche ${ }^{a}$, Chang Tan ${ }^{a *}$ \\ ${ }^{a}$ Dept. of Economics and Applied Economics, K.U.Leuven
}

September 19, 2005

\begin{abstract}
This paper provides empirical evidence of a more favorable tax treatment for foreign multinationals compared to similar domestic firms in a small open economy. Using treatment effects to control for self-selection of foreign firms into low tax firms, we find that foreign multinationals have substantially lower effective tax rates compared to domestic firms. In our estimations we also control for firm size, sector membership and business-cycle effects. A simple theoretical framework is used to explain our empirical findings and rests on the notion that multinational firms are in a better position to bargain for lower taxes with governments as a result of their "footloose" nature and outside location options.
\end{abstract}

Keywords: firm level data, multinationals, corporate taxation, self-selection

JEL classification: $\mathrm{C} 51, \mathrm{E} 62, \mathrm{~F} 23$

Address for correspondence: Hylke Vandenbussche, Catholic University of Leuven, Naamsestraat 69, 3000 Leuven, Belgium. T: + 32 (0) 163269 20, F: + 32 (0) 163267 32, email: hylke.vandenbussche@econ.kuleuven.be

${ }^{*}$ We thank participants of the LICOS seminar at the Catholic University of Leuven, a CORE workshop at Louvain-la-Neuve and participants of ETSG-Dublin 2005 for useful comments and feedback. In particular, we thank Harry Huizinga, Pascalis Raimondos-Møller and Jacques Thiss for useful comments and discussions. 


\section{Introduction and problem definition}

Corporate tax policy is one of the few remaining instruments that European countries have at their disposal in order to attract foreign investment. This is only one of the reasons why in recent years tax competition in Europe has intensified and official tax rates have been falling over time. In this paper we analyze to what extent a small open economy like Belgium tax discriminates between foreign owned multinationals (MNEs) and domestically owned firms. There are several reasons why the tax treatment of MNEs may differ from those of domestic firms.

Firstly, multinational firms are increasingly footloose and at the same time increasingly important in an economy. At the end of 1997 the added value of all multinational firms (MNE) in the world was approximately a quarter of the total added value in the world (Kind et al., 2001). In 2002, the stock represented foreign investments were on average $22 \%$ of the GNP of each country and the corresponding percentages for West European countries were still higher, between $31.4 \%$ and $42.7 \%$ (United Nations, 2003). The theoretical taxation literature suggests that governments indeed tend to favor mobile production factors (Haufler and Wooton, 1999, 2001).

Secondly, as Gresik (2001) points out, MNEs are flexible in terms of geographically organizing their production structure. This flexibility allows them to optimize their activities as a function of the tax policies in different countries which puts them in a better bargaining position vis-à-vis national tax authorities to obtain special treatment or tax rulings than purely domestic firms. Also, MNEs are usually more productive than domestic firms as documented by Griffith (1999). This productivity edge can have a positive influence on the technology of local companies and subcontractors and create positive spillovers (Javorcik, 2004).

Thirdly, the relationship between corporate taxation and the location of MNEs is an important issue on the political agenda of both the European Union and the OECD. As stated recently by the Commission of the European Union: "Now that a lot of internal trade barriers have been eliminated among the EU Member States and the internal markets for goods, labor and capital are more integrated, the allocation of capital (economic activity and investments) becomes more and more sensitive to differences in corporate taxation." The recent accession of the ten new EU Member States that all have very low corporate taxes has further accelerated this debate.

In addition, what is becoming more and more common practice is that large MNEs bargain with countries over the tax rate they will have to pay. The following quote from the Financial Times is a nice illustration of that:

Thursday April 14th 2005-04-21

"Sandoz, a Swiss pharmaceutical multinational has asked 3 countries in Europe to state what they could offer in terms of taxes and other benefits. The 
company is currently located in Vienna but is considering a move elsewhere in Europe in which financial and tax considerations are crucial as well as closeness to existing operations and to customers, in addition to access to the best people."

A comparison of Statutory Tax Rates (STR) across countries offers only a partial insight in terms of how attractive a particular country is to a MNE in terms of location. Complementary to the tax rate, also the tax base is an important element in the comparison of the tax burden across countries. The extent of depreciation allowances, interest deductions and other tax allowances that a country allows, are also important factors in the overall tax burden firms face. A measure that takes this into account is the so-called Effective Tax Rate (ETR). The difference between a country's official tax rate (STR) and the Effective Tax Rate (ETR) is a reflection of the amount of tax allowances a country offers.

In this paper we start by developing a simple model that illustrates why a country is inclined to tax MNE firms less than purely domestic firms. The distinctive feature of multinationals is that they have alternative location options. We use a simple bargaining framework between a firm and a country A, to show that a firm with an outside option in terms of location will be taxed lower than a firm that does not have that option.

Next, we engage in an empirical test of that theoretical prediction. We use a large data set of thousands of company accounts to analyze the difference in the corporate taxation of foreign owned multinationals (MNEs) and domestic firms, while at the same time controlling for other determinants that may explain the heterogeneity of firm level effective tax rates that we observe in the data.

In the next section we introduce the model. In section 3, we explain how we measure the Effective Tax Rate and in section 4 we discuss the empirical model that we use to test for tax differentiation between domestic and multinational firms, controlling for other factors that may explain the large extent of firm level heterogeneity in the Effective Tax Rates. Section 5 concludes.

\section{Theoretical framework}

In this section, we will develop a simple Nash bargaining model to show how the government of a particular country responds to outside options of MNE firms in term of tax treatment.

We assume there is only one firm. When the firm is a multinational it has two alternative locations. Either it sets up in country A, or it locates in country B. These locations are symmetric in the sense that set up costs and marginal production costs are assumed the same unless stated otherwise, therefore in comparing location A and B they will not affect the decision and can be dropped from the analysis. Whatever location is chosen, the ultimate objective of the firm is to supply a "third market" in country C. The reason why the firm can 
not set up in $\mathrm{C}$ could be that wage costs in $\mathrm{C}$ are so high that production there would not be profitable. We assume that $\mathrm{A}$ and $\mathrm{B}$ are equally far away from $\mathrm{C}$, therefore transport costs to final consumers in $\mathrm{C}$ are the same whether the firm sets up in A or B and can also be dropped from the analysis. With this simple model, we will show that a firm that bargains with country A over the tax rate on its profits, will obtain a lower tax rate as long as it has a credible outside location option. By assuming that the relevant market is a "third-market", we simplify the government objective function of country A since we can drop the consumer surplus from the objective function. The demand function in the relevant market $\mathrm{C}$ is

$$
P=\alpha-\gamma Q,
$$

where $P$ is the price and $Q$ is the quantity while $\alpha$ and $\gamma$ are both parameters with $\alpha>\gamma$. The production function of the firm is such that one unit of labor is required for one unit of output

$$
Q=L,
$$

where $L$ is labor, the only input for the production. The profit of the firm before tax is given by

$$
\pi=P Q-w L,
$$

where $w$ is the wage rate which is the same across country A and B.

The after-tax profit of the firm is

$$
\Pi=(P Q-w L)\left(1-t_{A}\right),
$$

where $t_{A}$ is the corporate tax rate in country A and $0<t_{A}<1$.

To simplify things we assume that the firm is a foreign owned multinational. Therefore whatever profits it generates, the after tax profits will be shifted abroad and do not enter the welfare function of country $\mathrm{A}^{1}$. We assume that the welfare function of country A consists of the wage bill from the employment and the tax income, thus the welfare function is as the following

$$
G=w L+t_{A} \pi,
$$

where $G$ stands for the government welfare. Or in terms of the after-tax profit the government welfare is

$$
G=w L+t_{A} \frac{1}{1-t_{A}} \Pi
$$

Country $\mathrm{B}$ is identical to country $\mathrm{A}$ except for the corporate tax rate $\overline{t_{B}}$ which is not subject to bargaining but is assumed exogenous and can therefore be treated as a parameter rather than a decision variable. The main reason for assuming it fixed is that we want to abstract from tax competition between

\footnotetext{
${ }^{1}$ We can relax this assumption and include the firm's after tax profits into the welfare function of A since it would not change our basic result, just make the algebra more complicated. But this suggests that it is not so much the ownership of the MNE that matters, but predominantly its "footloose" nature.
} 
countries, which complicates matters somewhat but which is not essential for the point we want to make namely that when a firm bargains with a country to get a favorable tax treatment, the footloose nature of the firm in terms of having an alternative location, will result in a lower equilibrium tax rate than when the firm is not footloose and can not "threaten" the government to move away to country B in the case where a deal is not struck with country A over a suitable tax rate.

The staging of the model is as follows. In the first stage country A and the firm bargain over the tax rate $t_{A}$. Then in the second stage, the MNE firm chooses its location, depending on where profits are highest. In the last stage, the firm chooses its output to supply market $\mathrm{C}$ to optimize its after-tax profit. The equilibrium tax rate is a subgame perfect Nash equilibrium, which is obtained through backward induction.

The equilibrium output from the final stage is as follows (the variables with star represent the equilibrium values)

$$
Q_{A}^{*}=Q_{B}^{*}=\frac{\alpha-w}{2 \gamma}
$$

The after tax profits of setting up in A or B are respectively

$$
\Pi_{A}^{*}=\frac{(\alpha-w)^{2}}{4 \gamma}\left(1-t_{A}\right)
$$

and

$$
\bar{\Pi}_{B}^{*}=\frac{(\alpha-w)^{2}}{4 \gamma}\left(1-\bar{t}_{B}\right)
$$

In the first stage the Nash bargaining product is given by

$$
\Omega=\left(G^{*}-G_{0}\right)^{\beta}\left(\Pi^{*}-\Pi_{0}\right)^{1-\beta},
$$

where $G_{0}$ and $\Pi_{0}$ represent the outside options for government $\mathrm{A}$ and the firm respectively. These outside options are what both country A and the firm would get in case the bargaining is not successful and both parties would walk away from the bargaining table without an agreement. We assume that if the "deal is off", country A ends up with nothing (no wage revenue and no tax revenue from the firm) or in other words that $G_{0}=0$. The firm's outside option is the profits it gets when moving to B. Or, in other words, in (11), we set $\Pi_{0}=\bar{\Pi}_{B}$. The parameter $\beta$ is a parameter representing the bargaining power of country $\mathrm{A}$ while $(1-\beta)$ is the bargaining strength of the firm. We assume this parameter to be exogenous and lies between zero and 1 . The Nash bargaining product therefore becomes

$$
\begin{aligned}
\Omega & =G^{* \beta}\left(\Pi^{*}-\bar{\Pi}_{B}^{*}\right)^{1-\beta} \\
& =\left[\frac{w(\alpha-w)}{2 \gamma}+\frac{t_{A}(\alpha-w)^{2}}{4 \gamma}\right]^{\beta}\left[\frac{(\alpha-w)^{2}}{4 \gamma}\left(\bar{t}_{B}-t_{A}\right)\right]^{1-\beta} .
\end{aligned}
$$


The first order condition of the Nash bargaining product gives the solution for the equilibrium tax rate in country $\mathrm{A}$

$$
\frac{\partial \ln \Omega}{\partial t_{A}}=0
$$

Consequently we get

$$
t_{A}^{*}=\beta \bar{t}_{B}-(1-\beta) \frac{2 w}{\alpha-w} .
$$

Let us now calculate the tax rate country A would set as a result of the bargaining process if the firm would not have an outside option to move to country B or put differently the outside option would be zero $\left(\Pi_{0}=0\right)$. In that case the Nash bargaining product becomes

$$
\begin{aligned}
\Omega & =\left(G-G_{0}\right)^{\beta}\left(\Pi-\Pi_{0}\right)^{1-\beta}=G^{* \beta} \Pi^{*(1-\beta)} \\
& =\left[\frac{w(\alpha-w)}{2 \gamma}+\frac{t_{A}(\alpha-w)^{2}}{4 \gamma}\right]^{\beta}\left[\frac{(\alpha-w)^{2}}{4 \gamma}\left(1-t_{A}\right)\right]^{1-\beta} .
\end{aligned}
$$

And the equilibrium tax rate becomes ${ }^{2}$

$$
\widetilde{t}_{A}^{*}=\beta-(1-\beta) \frac{2 w}{\alpha-w} .
$$

When we compare the solutions from the two models, we can get

$$
\begin{gathered}
\widetilde{t}_{A}^{*}-t_{A}^{*}=\left(1-\bar{t}_{B}\right) \beta \geq 0, \text { where } 0 \leq \bar{t}_{B} \leq 1 \\
\Rightarrow \widetilde{t}_{A}^{*} \geq t_{A}^{*} .
\end{gathered}
$$

This suggests that when the firm has an outside location option, the government sets a lower tax (or gives higher subsidy). Or, put differently when the firm is a footloose MNE that can threaten the government to locate elsewhere, the tax rate will be more favorable than for a firm without that alternative option.

Meanwhile, we can also obtain

$$
\frac{\partial t_{2}^{*}}{\partial \bar{t}_{B}}=\beta>0
$$

which means the tax rate of country $\mathrm{A}$ is complementary to the tax rate of country B.

\footnotetext{
${ }^{2}$ Note that the demand parameter $\gamma$ drops out in the calculation of the equilibrium tax rate.
} 


\section{How do we measure the Effective Tax Rate?}

Our calculation of the Effective Tax Rate (ETR) is based on the annual company accounts that firms publish each year and is often referred to as the average ETR (Callihan, 1994) $)^{3}$.

The definition of the average effective tax rate, common in the literature (i.e. Callihan (1994); Shackelford and Shevlin (2001); Buijink et al. (2002); Nicodème (2001); Janssen (2005)) is the firm level ratio of Tax Expenses (T) over pre-tax Income/Profits $(I)$.

$$
\text { Effective Tax Rate }\left(E T R_{i}\right)=\frac{\text { Tax Expenses }\left(T_{i}\right)}{\text { Profit Before } \operatorname{Tax}\left(I_{i}\right)} .
$$

The Tax Expenses $(T)$ are defined as Taxable Income $(T I)$ times the Statutory Tax Rate $(t)$

$$
T=T I \times t .
$$

But while we observe Tax Expenses and Profits Before Tax in our data, we do not observe Taxable Income. The difference between the Profit Before Tax $(I)$ and the Taxable Income $(T I)$ is referred to as Tax Preferences $(T P)^{4}$

$$
T P_{i}=I_{i}-T I_{i}, \text { or } T I_{i}=I_{i}-T P_{i} .
$$

Tax preferences include temporary and permanent differences between accounting profits and taxable income. Substituting $T I_{i}$ in (19) leads to a firm level measure of ETR

$$
E T R_{i}=\frac{\left(I_{i}-T P_{i}\right) \times t}{I_{i}}=\left(1-\frac{T P_{i}}{I_{i}}\right) \times t
$$

The above expression shows how firm level ETRs are affected by Tax Preferences $(T P)$, pre-tax Income/Profit $(I)$ and Tax Rate $(t)$ changes.

It can also be seen that if the tax base or Taxable Income $(T I)$ is equal to the pre-tax accounting profit, the Effective Tax Rate $(E T R)$ would equal the Statutory Tax Rate $(t)$. However, the tax base of a firm can differ from the pretax accounting profit. The fiscal authority can for example reject a number of expenses as non-deductibles which enlarge the tax base or it can exempt certain revenues from taxation (like dividend income from shareholdings in other firms) which reduce the tax base. Differences in ETR and STR reflect the extent of the tax preferences granted to a particular firm. In addition we should also

\footnotetext{
${ }^{3}$ An alternative ETR definition is the marginal ETR which is the tax rate to the additional unit of income from a specific investment project (Devereux et al., 2002). Marginal ETRs are better suited to investigate the effect of taxation on investment decisions. Marginal ETRs can also be used at the level of the firm as a whole, but of course the firm is a collection of investment projects, which makes the use of marginal ETRs at that level more problematic. Average ETRs are better suited to express the overall tax burden on the company because they express the rate of tax paid on company income.

${ }^{4}$ Tax preferences are the collective tax incentives provided by a government to firms which can consist in allowances, investment breaks or special rulings.
} 
point out that differences in STR and ETR may reflect the level of efficiency and frequency of tax audits of the fiscal authorities. In several countries the tax audits are usually organized through regional tax offices. An earlier paper by Vandenbussche et al. (2005) has shown that this may result in regional tax competition where the region which is relatively worse off economically has lower efficiency/enforcement than other regions.

\section{An Empirical Model to explain the firm level heterogeneity in Effective Tax Rates}

\subsection{Data and Empirical Model}

In this section we set out to analyze the determinants of effective taxation at the firm level in Belgium. Or in other words, we look for explanations as to why effective tax rates are so different over time and across firms. But as discussed above, there are several reasons why an individual firm may end up paying less than that. During the period of our analysis the official corporate tax rate for the Belgian firms in our sample was $40.17 \%^{5}$. The average Effective Tax Rate during the period of our analysis was much lower than that and in the range of $30 \%$. In this section we want to analyze amongst others whether there is a difference in effective tax rate between foreign owned Multinational (MNE) firms and domestic firms. For this purpose, we use unconsolidated firm-level data of non-financial firms ${ }^{6}$ between 1993 and 2002 from the AMADEUS database of Bureau van Dijk ${ }^{7}$.

To address our research question, we collected information on foreign ownership. In Amadeus we find 11,724 firms falling into the highest STR (40.17\%) pool in Belgium and 4,388 firms with information on shareholdings. In approximately $17.5 \%$ of the firms on which we have information on ownership structure, there is one majority foreign owner that holds $50 \%$ or more of the shares. This corresponds to 767 companies, which is somewhat less than $10 \%$ of all firms. Our definition of foreign ownership is a very strict one and differs from that used elsewhere in the literature. Since the focus in this paper is on tax discrimination between foreign MNEs and other firms, we want to make sure that the firms we single out as foreign owned are the most "footloose". Firms with 1 majority foreign owner that holds more than $50 \%$ of all shares is arguably the most footloose type of firm in our data since the foreign shareholder can easily "pack up and go" if he/she wants to. In contrast, take for example a firm that

\footnotetext{
${ }^{5}$ The statutory tax rate in Belgium follows a progressive system. This implies that smaller firms pay a smaller percentage profit tax than large firms. In our analysis of the Effective Tax Rates across firms, we only want to consider firms that fall under the same statutory tax rate. For that purpose we decided to focus on the largest firms in the highest STR-bracket which during the period of our analysis was $40.17 \%$.

${ }^{6}$ We exclude financial firms in NACE categories 65 to 67 because they are subject to a separate set of accounting rules and can not simply be compared with manufacturing and service firms.

${ }^{7}$ Other recent papers that have used AMADEUS data are Budd et al. (2005), Helpman et al. (2004), Huizinga and Nicodème (2005).
} 
has 5 foreign shareholders where each of the shareholders owns $20 \%$. This type of firm, while a $100 \%$ foreign owned firm is somewhat less "footloose" than a firm in which 1 foreign shareholder owns more than $50 \%$ of the shares. In the former case with 5 foreign shareholders, a (re)location decision would require an agreement between several of the shareholders, which is more difficult. This is an important difference with the paper by Huizinga and Nicodème (2005) where foreign ownership is included as a continuous variable, including firms with very small foreign participations and firms with scattered foreign ownership. In our opinion, firms with very small foreign participations or scattered foreign ownership are not really footloose and can almost be regarded as domestic firms since they can not threaten the government to locate elsewhere. While the minority foreign shareholder can sell whatever shares he/she has in a Belgian firm if not happy with his/her after tax return on investment, he/she does not have the majority of votes necessary to decide on (re)location. Recent other theoretical work by Huizinga and Nielsen (1997, 2000) and Kind et al. (2001), has shown that when foreign firms have a fixed location (are not allowed to move in the model), the government has an incentive to put a higher tax on the foreign firms compared to the domestic firms. Increased foreign ownership in a model with exogenous location, provides countries with an incentive to increase corporate tax levels, as it introduces the possibility of tax exportation. When domestic rents accrue to foreign residents, a country has a large incentive to tax them through the corporate tax system. This is also what Huizinga and Nicodème (2005) find empirically. However, the focus in this paper lies on the "footloose" nature of a firm. Both from a theoretical and an empirical point of view we find the opposite, namely that footloose MNEs pay less taxes than other firms. Here we should point out that the shareholder information is only available for the year 2002 and we assume it to hold during the entire period of our sample between 1993-2002.

In Table 1 we give a short overview of the characteristics of our dataset in terms of number of firms, average of employment by firms as well as average sales and average total assets. We report the data for the foreign owned firms and domestic firms in separate columns. We note that the foreign firms are on average larger both in terms of employment, sales and in terms of total assets than Belgian firms.

The empirical model explaining the heterogeneity of firm level ETRs is specified below in (23). The dependent variable on the left hand side captures the Effective Tax Rate (ETR) as defined in (19). It is worth pointing out here that our dependent variable controls implicitly for transfer pricing effects. To see that our empirical results are not driven by transfer pricing practices, consider the following numerical example. Suppose a MNE instead of $100 \$$ profits before tax, reports $150 \$$ as a result of transfer pricing considerations. Suppose further that the STR in the country in which the MNE reports additional profit equals $20 \%$. In principle, this would imply that the firm instead of $20 \$$ taxes in the absence of transfer pricing, now pays $30 \$$ taxes. However, in both cases the ETR would be the same and equal $20 \%$. Hence, transfer pricing affects numerator and denominator of the ETR ratio in a proportional way, suggesting that transfer pricing is not what we pick up. 
On the right hand side of (23) we include a number of variables that may explain the heterogeneity in ETRs. In our empirical model we include a dummy variable FOREIGN that takes the value of 1 when the firm is majority foreign owned by one foreign shareholder and takes a value of 0 when there is no majority foreign shareholder and a number of other control variables summarized in vector $Z$ :

$$
E T R_{i t}=\beta_{0}+\beta_{1} \text { FOREIGN } N_{i}+\beta_{2} Z_{i}+\varepsilon_{i t}
$$

where subscript $i$ is a firm level subscript and $t$ refers to the time period.

An overview of the control variables in $Z$ is given in Table 2 and we will discuss each of them briefly below. In order to control for the fact that foreign owned firms tend to be bigger than other firms, we include a measure of firm size (FIRMSIZE). We measure the variable FIRMSIZE by the "Number of Employees" of a company. We find a positive effect of FIRMSIZE on the ETR, or in other words that larger firms get fewer tax preferences and pay more taxes. Hence, the Belgian tax system is not entirely neutral with respect to this firm characteristic. One potential explanation put forward by Zimmerman (1983) is that large firms have more political visibility and are scrutinized more than smaller firms, making them pay more taxes than smaller firms.

In addition we also control for a number of other firm characteristics. First of all we include a series of variables that legally result in deductibles that lower the tax base (LEGAL) such as the capital intensity, which we define as the ratio of "Fixed Tangible Assets" over "Total Assets". When firms invest in capital (buildings, machinery and equipment etc.) they have depreciation allowances. The same holds for investment in "Intangible Fixed Assets" which we take as a proxy for the firms' expenditures on R\&D which also result in depreciation allowances. When the government makes $\mathrm{R} \& \mathrm{D}$ attractive in terms of the depreciation allowances, it helps private initiative and overcomes "free riding" problems and other issues which normally result in an under-investment in R\&D when left to the market. Through the tax system governments can provide incentives for firms to engage in more R\&D than they otherwise would undertake, which is likely to yield a better outcome in terms of social welfare. Other firm characteristics resulting in legal allowance are listed in Table 2 under "LEGAL" and in addition also include "Long-term Debt" and "Short-term Debt" since interests are usually considered as expenses that lower the reported profits and the tax base. Besides those, CF, a dummy variable standing for "Carryforward" is included to control for the tax treatment to loss in the previous year.

To control for the evolution of the Effective Tax Rate over time, we also include YEAR dummies in the empirical model (the year 1993 is our benchmark and will be dropped in the analysis).

As a last control variable we also include the SECTOR to which a firm belongs. We specify a sector at the 2-digit NACE industrial classification. The data at our disposal includes about 57, 2-digit NACE sectors in agriculture, manufacturing and services. While the sectors will be included as controls in 
the empirical model, for brevity, we will not report them separately.

Nevertheless to give an idea of sectoral heterogeneity, we show in Figure 1 the average ETR per sector. We can see that taxes are higher in some sectors than in others. The vertical line indicates the overall average for all sectors. In some sectors the ETR is clearly higher than the overall average like in the "construction sector", the "production of furniture and jewelry", the "wholesale and retail" and the "tanning and dressing of leather". Other sectors have below average ETRs, such as the "supplies of gas, water and electricity" (utility), the "real estate activities" sector and the "hotels and restaurants" sector.

The complete empirical model that we estimate then becomes:

$$
\begin{aligned}
E T R_{i t} & =\beta_{0}+\beta_{1} \text { FOREIGN }_{i}+\beta_{2} \text { FIRMSIZE }_{i t}+\beta_{3} L E G A L_{i t} \\
& +\beta_{4} \text { YEAR }_{i}+\beta_{5} \text { SECTOR }_{i}+\varepsilon_{i t} .
\end{aligned}
$$

\subsection{Results of the Empirical Model}

The results of estimating (24) are shown in Table 3. To check for robustness, we show several regression specifications in Table 3. The use of a fixed-effects regression is preferable whenever using firm-level data. The disadvantage of using fixed effects is however that the combination of fixed effects and other time-invariant variables, such as our ownership dummy (FOREIGN) is not possible. Since the ownership information that we have does not vary over time but are specific for each firm, they would be dropped out with a fixed effects specification.

Instead we use a set of other specifications. In column (1) we show the result of an OLS specification with both Robust White corrected standard errors, which controls for possible heteroskedasticity of the observations, and clusters where we consider each firm as a separate cluster. The reason for the clustered regression is that the observations of one firm over time can be correlated. Since observations over time from the same firm are not necessarily independent of each other, we consider each firm as a separate "cluster" in the regression. In columns (2), we use a "censored tobit regression" that takes into account the censoring we applied on our dependent variable. We truncated the observations for each firm's ETR by keeping only values lying between 0 and 1 (like in Collins and Shackelford (1995)). In Figure 2 we illustrate the total distribution of nontruncated ETRs in the dataset. Here we can see a number of observations lying below 0 or above 1 . ETRs below 0 can reflect losses instead of profits in the denominator. To avoid this, we only incorporate the observations with positive profits in our dataset. ETRs above 1 can be the result of tax fines that a firm must pay with respect to profits of previous years. We also disregard those observations. However these truncations on the dependent variable could bias our empirical estimates. Hence in column (2) we report the results using the censored tobit regression. In column (3) of Table 3 we estimate a dynamic model. 
This implies that we include an extra explanatory variable namely the lagged ETR. In order to control for potential first order serial correlation, we prefer to lag the ETR by two periods (ETR_2). The variable has high positive significance in the model suggesting it is important to be included. In the dynamic specification, we no longer take year dummies on board as control variables, since arguably the lagged value controls for the evolution of ETRs over time.

Finally in column (4a) and (4b) we want to control for the so-called "selfselection" problem. It is possible that foreign shareholders only invest in companies with low ETRs. If this form of "cherry picking" is going on, this would give rise to an econometric problem of endogeneity. Or, put differently foreign ownership would become a function of ETR. To control for this potential endogeneity problem, we apply a correction to the estimation procedure known as the "treatment effects" (similar to Heckman's two-step estimation) (Greene, 2000). The first step of this two-step estimation consists in estimating a probit equation to obtain the probability of being foreign owned. This results in a hazard rate (also referred to as the Inverse Mills Ratio) that is included as an extra regressor in the second stage regression to obtain an unbiased estimate for the FOREIGN dummy. For the remainder this second step regression is the same as described in (24). The first step probit equation we used is the following:

$$
\begin{aligned}
\text { FOREIGN }_{i}= & \gamma_{0}+\gamma_{1} \text { FIRMSIZE }_{i t}+\gamma_{2} \text { LEGAL }_{i t} \\
& +\gamma_{3} \text { SECTOR }_{i}+\gamma_{4} \text { PRODUCTIV }_{i t}+\mu_{i t} .
\end{aligned}
$$

Typically in a "treatment effects" approach, the first step right hand side variables are partly the same as in the model for ETR. However for identification purposes at least one extra variable is needed in the first step "selection equation". Recent theoretical literature has shown that foreign owned MNE firms are the more productive firms (Helpman et al., 2004) and there is empirical evidence in support of that (Griffith, 1999). Therefore we feel it is reasonable to include labor productivity (PRODUCTIV) as an extra variable in the selection equation $^{8}$. We measure labor productivity as "value added per worker". This value is further normalized by the mean across firms within the relevant 2-digit Nace industry in that year. This normalization means that we do not need to measure Producer Price Indices, which is notoriously difficult to obtain in service and other industries except for manufacture industry ${ }^{9}$ (Griffith et al., 2004). The results of this first step are reported in Table 3 in column (4b). In column (4a) we report the coefficients of the step 2 estimation where the inverse mills ratio (based on the step 1 equation) is included as an extra regressor. The coefficient on the inverse mills ratio that is reported at the bottom of column (4a) is positive and significant suggesting that there is a selection issue. This suggests that in an OLS regression without correction for selection, the coefficient is biased upward (Greene (2000), p759). Or in other words is estimated

\footnotetext{
${ }^{8}$ We experimented also with other control variables like Return on Assets and Return on Equity. The choice for the extra variable doesn't make a difference for the coefficient of our key variable foreign ownership dummy.

${ }^{9}$ We have also regressed a subset for only manufacture sectors (with 2-digit NACE between 10 and 41) with real labor productivity, which means the labor productivity has been deflated by Producer Price Index. The main results are similar to those for the non-deflated total set.
} 
larger than its true value. Indeed when we compare the coefficient on the foreign dummy in column (4a) we see that it is smaller (more negative) than the one we obtained under OLS in column (1). In our case it means that the tax discrimination of foreign firms is larger than what the OLS estimates suggested. For completeness we give a short overview of the two-step Heckman procedure in the appendix.

A general observation that arises from Table 3 is that our results remain quite stable across the different estimation methods. In each of the specifications where we included the variable FOREIGN it always has a negative sign and is very significant. When we do not check for self-selection, the coefficient of the variable FOREIGN varies between -0.014 and -0.040 , which implies that the ETRs of foreign firms lie on average between $1.4 \%$ and $4 \%$ lower than those for domestic firms. Since the average ETR for the whole dataset is around $30 \%$, we can say that the average ETR for the foreign firms lies approximately between $26 \%$ and $28.6 \%$. In other words, the effective tax rate for foreign companies is approximately $9 \%$ lower than the average $([0.014+0.04) / 2] / 0.30)$.

However, when we consider the possibility that foreign shareholders "select" themselves into firms with low ETR, that is when we check for "self-selection", the coefficient goes to a value of -0.221 . This suggests that when we control for self-selection the tax difference between foreign owned multinationals and domestic firms is even larger. Controlling for self-selection means that foreign multinationals have a tax burden of approximately $22.1 \%$ points lower relative to the average, or suggests that foreign owned firms have an average ETR of about $7.9 \%(30 \%-22.1 \%)$. This is approximately $73.7 \%$ lower than what Belgian firms $(0.221 / 0.30)$ pay in terms of average ETR.

Regarding the other control variables, all specifications more or less give the same results. The FIRMSIZE variable has a positive and significant coefficient. In Belgium, larger firms seem to pay more taxes. In other words the tax system in Belgium is unfriendly for employment. The R\&D Intensity variable and the Capital Intensity variable are negative and significant for Belgium. The estimate of labor productivity in the first stage of the treatment effects regression is positive and significant which indicates that the MNE firms are also more productive than domestic firms in Belgium as what is found in UK by Griffith (1999).

When we look at the YEAR dummies, we see that the effective tax burden has increased over time for Belgian firms, especially in the period 1999-2002, which was the period just prior the tax reform the Belgian government introduced in 2002. The main element in the tax reform was that the Statutory Tax Rate was lowered from $40.17 \%$ to $33.99 \%$. This seems to suggest that the tax base was widened in the years that directly before the tax reform. This phenomenon of enlarged tax bases coinciding with decreasing tax rates has also been observed in other European countries. Most EU countries that are also in the EURO-zone, are confined by the Maastricht budget criteria and have an incentive to make sure that any reduction in the official tax rate is budget neutral. The only way 
this can be achieved is through widening the tax base, which is apparently also true for the Belgian case.

The results in Table 3 also suggest that debt financing always seems to reduce the Effective Tax Rate. This seems to confirm the notion that equity financing is disadvantaged which may explain why the Belgian government in 2005 is considering to implement a tax deduction for equity financing ${ }^{10}$.

\subsection{Discussion of results}

The empirical section above confirmed our theoretical model in section 2. Based on firm level data for Belgium, we find that the government tax discriminates between firms in favor of footloose multinationals. These results are also in line with a recent theory paper by Haufler and Wooton (1999). That paper shows that a "small" country has an incentive to give more tax breaks to a footloose firm than a large country. The reason is that an MNE prefers to be in the large country to save on transport costs when serving its consumers. Therefore a large country has far less of an incentive to provide tax cuts to multinationals, whereas a small country in order to attract a multinational will have to overcome the fact that it is smaller and it can do so by offering the multinational a more favorable treatment compared to the large country. The tax rate in equilibrium offered by the small country will be low enough for the multinational to overcome the additional transport costs it will face when supplying its customers in the large country from a distance.

The tax discrimination we find between footloose MNEs and other firms is not driven by transfer pricing. The dependent variable in our regression is the Effective Tax Rate (ETR) defined as the ratio of "Tax Expenses/Profits Before Tax". With a numerical example it is easy to show that both in the absence or the presence of transfer prices, the ETR is the same. The reason is that transfer pricing affects numerator and denominator of the ETR ratio in a proportional way. If a firm decides to report more profits before tax in one country for transfer pricing reasons, it will proportionally pay more taxes in the reporting country. While this could be of interest to the firm since this may minimize its global tax bill especially when the tax rate in the country it decides to report more profits is a low tax rate, it does not interfere with the question we want to analyze in this paper, namely whether foreign owned MNEs pay less taxes than domestic firms. This implies that our results are not driven by transfer pricing issues. Other definitions of ETR sometimes used in the literature are more prone to transfer pricing issues. For example in when ETR is defined as "Tax Expenses / Total Assets" as in Huizinga and Nicodème (2005). In this definition of ETR, the numerator is affected through transfer pricing, while the denominator is not. "Total Assets" in the denominator of the ETR variable can not eliminate the influence of transfer pricing on the tax burden of MNE firms who have opportunities to shift profits (but not assets).

\footnotetext{
${ }^{10} \mathrm{PwC}$ Tax Newsletter, April 2005, "Introduction of the Concept of 'Notional Interest Deduction' into Belgian Tax Law".
} 


\section{Conclusion}

This paper aims to contribute to the debate in the corporate taxation literature on the effect of increased economic integration and mobility of firms on corporate tax rates. Using a simple theoretical framework we show that governments are inclined to tax "footloose" firms less than other firms.

Empirically we proxy the footloose nature of firms by identifying in our data all majority foreign owned multinational firms in Belgium; that is we identify all firms that have one foreign owner that holds more than $50 \%$ of all shares.

Our empirical evidence, based on firm level data in a small open economy Belgium, confirms that there is substantial tax discrimination in favor of "footloose" MNE firms. The tax discrimination effects are largest when we control for selfselection of foreign firms into low effective tax firms by means of a "treatment effects" approach.

We should point out that the ownership information in our data is time invariant, therefore our results are mainly obtained through the cross-sectional variation in ownership across firms. Our results are robust across a range of alternative estimation techniques. 


\section{References}

Budd, J., J. Konings, and M. Slaughter (2005): "Wages and International Rent Sharing in Multinational Firms," Review of Economics and Statistics, Vol. 87, Issue 1, pp. 73-84.

Buijink, W., B. Janssen, And Y. Schols (2002): "Evidence of the Effect of Domicile on Corporate Average Effective Tax Rates in the European Union," Journal of International Accounting Auditing and Taxation, Vol. 11, pp. 115-130.

Callihan, D. (1994): "Corporate Effective Tax Rates: A Synthesis of the Literature," Journal of Accounting Literature, Vol. 13, pp.1-43.

Collins, J. H. ANd D. Shackelford (1995): "Corporate Domicile and Average Effective Tax Rates: The Cases of Canada, Japan, the United Kingdom, and the United States," International Tax and Public Finance, Vol. 2, No. 1, pp. 55-83.

Devereux, M., R. Griffith, and A. Klemm (2002): "Corporate Income Tax Reforms and International Tax Competition," Economic Policy, Vol. 17, pp. 451-495.

Greene, W. H. (2000): Econometric Analysis, Upper Saddle River (N.J.): Prentice Hall International.

Gresik, T. (2001): "The Taxing Task of Taxing Transnationals," Journal of Economic Literature, Vol. 39, pp. 800-838.

Griffith, R. (1999): "Using the ARD Establishment Level Data to Look at Foreign Ownership and Productivity in the United Kingdom," Economic Journal, Vol. 109, No. 456, pp. F416-F442.

Griffith, R., S. Redding, And H. Simpson (2004): "Foreign Ownership and Productivity: New Evidence from the Service Sector and the R\&D Lab," CEP Discussion Paper, No. 649.

Haufler, A. And I. Wooton (1999): "Tax Competition for Foreign Direct Investment," Journal of Public Economics, Vol. 71, pp. 121-139.

(2001): "Regional Tax Coordination and Foreign Direct Investment," CEPR Discussion Paper, No. 3063.

Helpman, E., M. J. Melitz, and S. Yeaple (2004): "Export versus FDI with Heterogeneous Firms," American Economic Review, Vol. 94, No. 1, pp. 300-316.

Huizinga, H. And G. NicodÈme (2005): "Foreign Ownership and Corporate Income Taxation: An Empirical Evaluation," European Economic Review, forth coming.

Huizinga, H. And S. Nielsen (1997): "Capital Income and Profit Taxation with Foreign Ownership of Firms," Journal of International Economics, Vol. 42, pp. 149-165.

(2000): "The Taxation of Interest in Europe: a Minimum Withholding Tax," Taxing Capital Income in the European Union, Issues and Options for Reform, Cnossen S. ed., Oxford University Press, Oxford. 
Janssen, B. (2005): "Corporate Effective Tax Rates in the Netherlands," De Economist, Vol. 153, No. 1, pp. 47-66.

Javorcik, B. (2004): "Does Foreign Direct Investment Increase the Productivity of Domestic Firms? In Search of Spillovers through Backward Linkages," American Economic Review, Vol. 94, No. 3, pp. 605-627.

Kind, H., K. Midelfart, and G. Schjelderup (2001): "Corporate Taxation, Multinational Entreprise and Economic Integration," CEPR Discussion Paper, No. 2753.

Nicodème, G. (2001): "Computing Effective Corporate Tax Rates: Comparisons and Results," DG ECFIN Economic Paper, No. 153.

Shackelford, D. And T. Shevlin (2001): "Empirical Tax Research in Accounting," Journal of Accounting and Economics, Vol. 34, No. 1-3, pp. 321-387.

Vandenbussche, H., B. Janssen, and K. Crabbé (2005): "Regional Tax Competition. Evidence for Belgium," De Economist-Netherland, October.

Zimmerman, J. (1983): "Taxes and Firm Size," Journal of Accounting and Economics, Vol. 5, pp. 119-149. 
Table 1: Summary statistics of Belgian firms and foreign owned firms

\begin{tabular}{|c||c|c|}
\hline & Foreign-owned firms & Domestic firms \\
\hline Number of Firms & 767 & 3,621 \\
\hline Average Employment & 164.62 & 65.67 \\
& $(543.82)$ & $(280.23)$ \\
\hline Average Sales (Th. Euro) & $64,415.93$ & $26,231.13$ \\
& $(249,108.9)$ & $(102,075.6)$ \\
\hline Average Total Assets (Th. Euro) & $93,943.85$ & $34,077.03$ \\
& $(589,702.7)$ & $(196,044.8)$ \\
\hline
\end{tabular}

Source: Amadeus, Bureau Van Dijk

Note: standard deviations between brackets

Table 2: Variables in the model of Effective Tax Rates (ETR)

\begin{tabular}{|c|c|}
\hline Variables & Descriptions \\
\hline FOREIGN & $\begin{array}{l}\text { A dummy variable which takes value } 1 \text { for a firm i with at } \\
\text { least } 50 \% \text { shares in the hands of a foreign shareholder and } \\
\text { value } 0 \text { if there is no foreign majority shareholder. }\end{array}$ \\
\hline FIRMSIZE & $\begin{array}{l}\text { The size of a company measured by the natural logarithm of } \\
\text { the number of employees. }\end{array}$ \\
\hline LEGAL & \\
\hline LTLEVERAGE & $=$ Long-term debt $/$ total assets \\
\hline STLEVERAGE & $=$ Short-term debt $/$ total assets \\
\hline CAPITALINTENS & $=$ Tangible fixed assets $/$ total assets \\
\hline R\&D INTENS & $=$ Intangible fixed assets $/$ total assets \\
\hline CF (carry-forward) & $\begin{array}{l}\text { A dummy variable which takes value } 1 \text { when firm i made } \\
\text { losses in the previous year and value } 0 \text { if profit achieved } \\
\text { instead. }\end{array}$ \\
\hline YEAR & $\begin{array}{l}\text { Dummy variables which are made for each year between } 1993 \\
\text { and } 2002 . \text { The year } 1993 \text { is taken as a benchmark so that the } \\
\text { dummy for } 1993 \text { is left from the model. }\end{array}$ \\
\hline SECTOR & $\begin{array}{l}57 \text { dummy variables based on 2-digit NACE and } 1 \text { sectors left } \\
\text { as benchmark. }\end{array}$ \\
\hline PRODUCTIV & $\begin{array}{l}\text { Value added per worker. We normalize the labor productivity } \\
\text { with the mean across the industry in terms of 2-digit NACE } \\
\text { code in that year. }\end{array}$ \\
\hline ETR_2 & 2 periods lagged variable for ETR. \\
\hline
\end{tabular}


Figure 1: Average ETR by sector

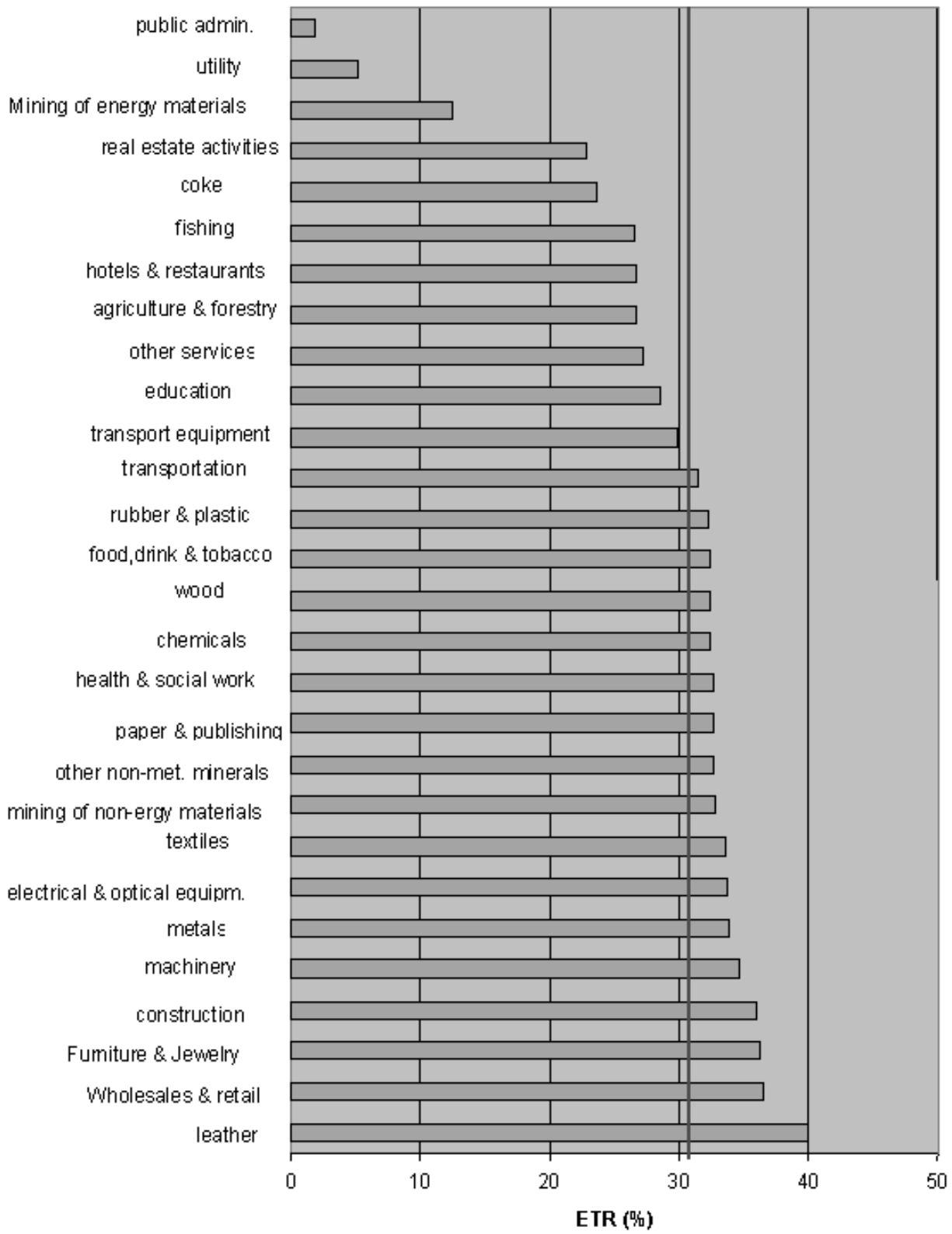


Table 3: Estimates of the regression analysis for the model of the Effective Tax Rate

$$
\begin{aligned}
E T R_{i t} & =\beta_{0}+\beta_{1} \text { FOREIGN }_{i}+\beta_{2} \text { FIRMSIZE }_{i t}+\beta_{3} L E G A L_{i t} \\
& +\beta_{4} Y E A R_{i}+\beta_{5} S E C T O R_{i}+\varepsilon_{i t} .
\end{aligned}
$$

\begin{tabular}{|c|c|c|c|c|c|}
\hline & $\begin{array}{c}(1) \\
\text { Robust } \\
\text { Clustered } \\
\text { Regression }\end{array}$ & $\begin{array}{c}(2) \\
\text { Censored } \\
\text { Tobit } \\
\text { Regression }\end{array}$ & $\begin{array}{c}(3) \\
\text { Dynamic } \\
\text { Model }\end{array}$ & $\begin{array}{c}\text { (4a) } \\
\text { Treatment } \\
\text { Effects } \\
\text { Model } \\
\text { (2nd stage) } \\
\end{array}$ & $\begin{array}{c}\text { (4b) } \\
\text { Treatment } \\
\text { Effects } \\
\text { Model } \\
\text { (1st stage) }\end{array}$ \\
\hline FOREIGN & $\begin{array}{c}-0.032^{* * *} \\
(0.006)\end{array}$ & $\begin{array}{c}-0.040^{* * *} \\
(0.004)\end{array}$ & $\begin{array}{c}-0.014^{* * *} \\
(0.004)\end{array}$ & $\begin{array}{c}-0.221^{* * *} \\
(0.034)\end{array}$ & - \\
\hline FIRMSIZE & $\begin{array}{c}0.011^{* * *} \\
(0.002)\end{array}$ & $\begin{array}{c}0.013^{* * *} \\
(0.001)\end{array}$ & $\begin{array}{c}0.004^{* * *} \\
(0.001)\end{array}$ & $\begin{array}{c}0.028^{* * *} \\
(0.003)\end{array}$ & $\begin{array}{c}0.271^{* * *} \\
(0.010)\end{array}$ \\
\hline CAPITALINTENS & $\begin{array}{c}-0.069^{* * *} \\
(0.014)\end{array}$ & $\begin{array}{c}-0.074^{* * *} \\
(0.009)\end{array}$ & $\begin{array}{l}-0.009 \\
(0.010)\end{array}$ & $\begin{array}{c}-0.093^{* * *} \\
(0.012)\end{array}$ & $\begin{array}{c}-0.762^{* * *} \\
(0.070)\end{array}$ \\
\hline R\&D INTENS & $\begin{array}{c}-0.107^{* * * *} \\
(0.043)\end{array}$ & $\begin{array}{c}-0.161^{* * *} \\
(0.031)\end{array}$ & $\begin{array}{c}0.004 \\
(0.035)\end{array}$ & $\begin{array}{c}-0.094^{* * *} \\
(0.035)\end{array}$ & $\begin{array}{l}-0.072 \\
(0.234)\end{array}$ \\
\hline LTLEVERAGE & $\begin{array}{c}-0.068^{* *} \\
(0.022)\end{array}$ & $\begin{array}{c}-0.187^{* * *} \\
(0.009)\end{array}$ & $\begin{array}{c}-0.028^{* * *} \\
(0.011)\end{array}$ & $\begin{array}{c}-0.112^{* * *} \\
(0.010)\end{array}$ & $\begin{array}{c}0.075 \\
(0.065)\end{array}$ \\
\hline STLEVERAGE & $\begin{array}{c}-0.187^{* * *} \\
(0.017)\end{array}$ & $\begin{array}{c}-0.262^{* * *} \\
(0.012)\end{array}$ & $\begin{array}{c}0.100^{* * *} \\
(0.013)\end{array}$ & $\begin{array}{c}-0.188^{* * *} \\
(0.012)\end{array}$ & $\begin{array}{l}0.136^{*} \\
(0.078)\end{array}$ \\
\hline $\mathrm{CF}$ & $\begin{array}{c}-0.228^{* * *} \\
(0.005)\end{array}$ & $\begin{array}{c}-0.352^{* * *} \\
(0.006)\end{array}$ & $\begin{array}{c}-0.174^{* * *} \\
(0.005)\end{array}$ & $\begin{array}{c}-0.232^{* * *} \\
(0.005)\end{array}$ & - \\
\hline PRODUCTIV & - & - & - & - & $\begin{array}{c}0.046^{* * *} \\
(0.008)\end{array}$ \\
\hline ETR_2 & - & - & $\begin{array}{c}0.406^{* * *} \\
(0.010)\end{array}$ & - & - \\
\hline 1994 & $\begin{array}{c}0.041^{* * *} \\
(0.005)\end{array}$ & $\begin{array}{c}0.051^{* * *} \\
(0.007)\end{array}$ & - & $\begin{array}{c}0.048^{* * *} \\
(0.008)\end{array}$ & - \\
\hline 1995 & $\begin{array}{c}0.037^{* * *} \\
(0.005)\end{array}$ & $\begin{array}{c}0.046^{* * *} \\
(0.007)\end{array}$ & - & $\begin{array}{c}0.036^{* * *} \\
(0.008)\end{array}$ & - \\
\hline 1996 & $\begin{array}{c}0.044^{* * * *} \\
(0.006)\end{array}$ & $\begin{array}{c}0.055^{* * * *} \\
(0.007)\end{array}$ & - & $\begin{array}{c}0.044^{* * *} \\
(0.008)\end{array}$ & - \\
\hline 1997 & $\begin{array}{c}0.045^{* * *} \\
(0.006)\end{array}$ & $\begin{array}{c}0.055^{* * *} \\
(0.007)\end{array}$ & - & $\begin{array}{c}0.045^{* * *} \\
(0.008)\end{array}$ & - \\
\hline 1998 & $\begin{array}{c}0.040^{* * *} \\
(0.006)\end{array}$ & $\begin{array}{c}0.050^{* * *} \\
(0.007)\end{array}$ & - & $\begin{array}{c}0.040^{* * *} \\
(0.007)\end{array}$ & - \\
\hline 1999 & $\begin{array}{c}0.052^{* * *} \\
(0.006)\end{array}$ & $\begin{array}{c}0.066^{* * *} \\
(0.007)\end{array}$ & - & $\begin{array}{c}0.056^{* * *} \\
(0.007)\end{array}$ & - \\
\hline 2000 & $\begin{array}{c}0.048^{* * * *} \\
(0.006)\end{array}$ & $\begin{array}{c}0.062^{* * *} \\
(0.007)\end{array}$ & - & $\begin{array}{c}0.053^{* * *} \\
(0.007)\end{array}$ & - \\
\hline 2001 & $\begin{array}{c}0.052^{* * *} \\
(0.006)\end{array}$ & $\begin{array}{c}0.065^{* * *} \\
(0.007)\end{array}$ & - & $\begin{array}{c}0.058^{* * *} \\
(0.007)\end{array}$ & - \\
\hline 2002 & $\begin{array}{c}0.043^{* * *} \\
(0.006)\end{array}$ & $\begin{array}{c}0.055^{* * *} \\
(0.007)\end{array}$ & - & $\begin{array}{c}0.053^{* * *} \\
(0.007)\end{array}$ & - \\
\hline SECTOR & Yes & Yes & Yes & Yes & Yes \\
\hline CONSTANT & $\begin{array}{c}0.224^{* * *} \\
(0.039)\end{array}$ & $\begin{array}{c}0.179^{* * *} \\
20(0.023)\end{array}$ & $\begin{array}{c}0.155^{* * *} \\
(0.027)\end{array}$ & $\begin{array}{c}0.195^{* * *} \\
(0.037)\end{array}$ & $\begin{array}{l}-7.186 \\
(0.408)\end{array}$ \\
\hline LAMBDA & - & - & - & $\begin{array}{c}0.114^{* * *} \\
(0.020)\end{array}$ & - \\
\hline No. of Observations & 25,222 & $\overline{25,222}$ & $\overline{9,223}$ & 15,997 & 15,9 \\
\hline
\end{tabular}


Figure 2: Distribution of ETRs

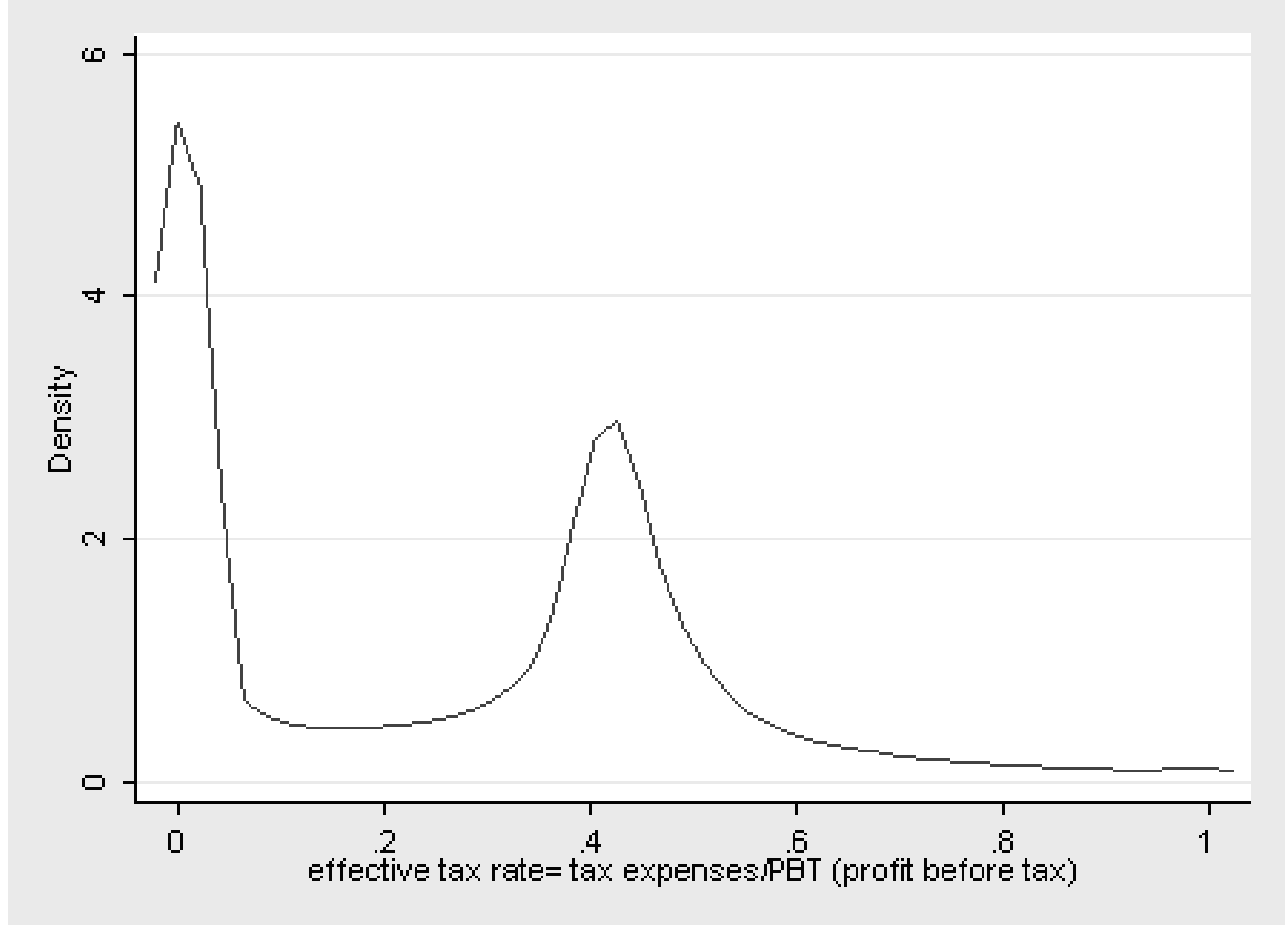

\section{A Appendix: a two-step Heckman estimation}

The primary interest is in the regression function:

$$
E T R_{i t}=X_{i t} \beta+\delta \text { fown }_{i}+\varepsilon_{i t},
$$

where fown $_{i}$ is an endogenous dummy variable indicating whether the treatment is assigned or not. The binary decision to obtain the treatment fown $n_{i}$ is modeled as the outcome of an unobserved latent variable, fown $n_{i}^{*}$. It is assumed that fown $n_{i}^{*}$ is a linear function of a set of exogenous variables $\left(W_{i t}\right)$, which can be the same as $X_{i t}$ in (26) but at least one extra variable is needed for identification, and a random component $\mu_{j}$. Specifically,

$$
\text { fown }_{i t}^{*}=W_{i t} \gamma+\mu_{i t},
$$

and the observed decision is

$$
\text { fown }_{i t}= \begin{cases}1, & \text { if } \text { fown }_{i t}^{*}>0 \\ 0, & \text { otherwise }\end{cases}
$$

The probit estimates of the treatment equation ( 27) is obtained by maximum likelihood in the first stage, as 


$$
\operatorname{Pr}\left(\text { fown }_{i}=1 \mid W_{i t}\right)=\Phi\left(W_{i t} \gamma\right) .
$$

From these estimates, the hazard rate, $h_{i}$, for each observation is computed as

$$
h_{i}= \begin{cases}\phi\left(W_{i t} \hat{\gamma}\right) / \Phi\left(W_{i t} \hat{\gamma}\right), & \text { fown }_{i}=1 \\ -\phi\left(W_{i t} \hat{\gamma}\right) /\left\{1-\Phi\left(W_{i t} \hat{\gamma}\right)\right\}, & \text { fown }_{i}=0 .\end{cases}
$$

where $\phi$ is the standard normal density, and $\Phi$ is the standard normal cumulative distribution function. In the second stage, the two-step parameter estimates of $\beta$ and $\delta$ are obtained by augmenting the regression equation with the hazard (inverse mills ratio) $h$. Then,

$$
E\left(E T R_{i t} \mid \text { fown }_{i}\right)=X_{i t} \beta+\delta \text { fown }_{i t}+\beta_{h} h_{j}
$$

And we obtain the additional coefficient $\beta_{h}$ on the variable containing the hazard. When $\beta_{h}$ is significantly different from zero there exists a self-selection problem and including the hazard rate (inverse mills ratio) in step 2 will correct for it. From estimating ( 31 ) the coefficient $\delta$ on fown will now be correctly estimated. 